\title{
Man Created God in His Image: A Review of Hector Garcia, Alpha God: The Psychology of Religious Violence and Oppression
}

\author{
Nicole Barbaro ${ }^{1}$ \\ Published online: 5 January 2016 \\ (C) Springer International Publishing 2016
}

Tooby, and incorporates research from primatologists, such as Frans de Waal, Barbara Smuts, and Richard Wrangham, to advance an evolutionary psychological account of religious violence and oppression. Underpinned by the principles of sexual selection, in particular, Garcia elegantly demonstrates the broad applicability of an evolutionary psychological perspective for understanding human behavior - drawing on central theories of evolutionary psychology, including sexual strategies theory (Buss and Schmitt 1993), kin selection theory (Hamilton 1964), and sperm competition theory (Parker 1970), to name a few.

Garcia's analysis focuses on the origins of monotheistic Gods through the lens of the evolutionary sciences. He reverses the standard creationist dogma purporting that God created man in His image, with the brilliant logic afforded by an evolutionary scientific analysis. Garcia argues that religious beliefs are produced by evolved psychological mechanisms designed to detect status and dominance, particularly among men. He describes how humans' evolutionary history of living in status hierarchies is responsible for an evolved "alpha male" psychology. Central to his thesis, he contends that the qualities of dominant alpha males were imported onto the Abrahamic God. Put differently, Garcia claims that God was created in the image of man.

Garcia makes a powerful case that the dominant God of the Abrahamic religions is the expression of an extreme, all-powerful, mortal (human) alpha male. He notes that "The power of evolutionary knowledge is that it unveils the designs of dominant men and allows us to rend apart those conflations with God that create enmity and bloodshed" (p. 61). Across the animal kingdom, dominant males deploy violence as a means to intimidate subordinates, acquire territory, control female sexuality, and maintain dominance and status within the group 
(Buss and Shackelford 1997). Garcia points out that these same evolutionary functions underlying an alpha males' use of violence also underlie God's use of violence. In the Abrahamic religions, God serves as the protector of the ingroup, regulates female sexuality, justifies and promotes violence toward out-groups, and requires submission to Him that is maintained through dominance and prestige. Garcia tackles each function of violence separately, meticulously documenting the striking parallels between alpha male psychology in great apes, men, and God. He demonstrates how religious beliefs mesh seamlessly with our existing psychological mechanisms that afford violence and the oppression and control of sexuality.

Garcia's argument that the origins of God and religiously motivated violence are rooted in our evolved psychology is powerful but bound to be upsetting for many outside of the evolutionary sciences. He contends, however - as many evolutionary scientists studying "hot button" topics do- that our evolved psychology does not dictate our behavior. Humans, in particular, have the remarkable capacity to reflect on our thoughts and behaviors and, therefore, have the ability to not succumb to our evolutionary rooted (violent) tendencies. Garcia notes that:

"While there are potential remedies to the problems engendered by this alpha god, his image is so deeply rooted in our evolved psychology that it is uncertain to what extent solutions can gain traction on a global scale. Boldly unveiling the male primate puppeteers of God will be a necessary first step." (p. 223)

Garcia concludes Alpha God with a chapter on "Righting Ourselves" in which he argues for the application of the evolutionary sciences to curb religiously motivated violence. Among his solutions, Garcia advocates that freedom of information, (actual) separation of church and state, and proper evolutionary education are basic conditions needed for productive steps toward decreasing religiously motivated violence between and within nations.

In conclusion, Garcia provides a startling reversal for the origins of the Abrahamic alpha gods-our evolved psychological mechanisms. Engaging and accessible, with a laser focus on our deep primate evolutionary history, Alpha God provides something for anyone with a general curiosity about the human condition. Casual readers will gain insight to the evolved psychology of apes and men. Religious believers will be offered an alternative explanation concerning the God to which they are devoted. And academics can appreciate the applicability of evolutionary principles to human psychology and behavior. Garcia offers a powerful starting point to the evolutionary analysis of the some of the dark consequences of religious belief. However, an astonishing number of questions concerning the psychology of religion remain for researchers - which the evolutionary sciences have only begun to tackle.

\section{References}

Buss, D. M., \& Schmitt, D. P. (1993). Sexual strategies theory: An evolutionary perspective on human mating. Psychological Review, 100, 204.

Buss, D. M., \& Shackelford, T. K. (1997). Human aggression in evolutionary psychological perspective. Clinical Psychology Review, 17, 605-619.

Hamilton, W. D. (1964). The genetical evolution of social behaviour. I. Journal of Theoretical Biology, 7, 1-16.

Parker, G. A. (1970). Sperm competition and its evolutionary effect on copula duration in the fly Scatophaga stercoraria. Journal of Insect Physiology, 16, 1301-1328.

Sela, Y., Shackelford, T. K., \& Liddle, J. R. (2015). When religion makes It worse: Religiously motivated violence as a sexual selection weapon. In J. Slone \& J. Van Slyke (Eds.), The attraction of religion: A new evolutionary psychology of religion (pp. 111-131). New York: Bloomsbury Academic. 